\title{
Front Matter: Volume 7807
}

, "Front Matter: Volume 7807," Proc. SPIE 7807, Earth Observing Systems XV, 780701 (1 October 2010); doi: 10.1117/12.878569

EDIE Event: SPIE Optical Engineering + Applications, 2010, San Diego, California, SPIE. United States 


\section{PROCEEDINGS OF SPIE}

\section{Earth Observing Systems XV}

James J. Butler

Xiaoxiong Xiong

Xingfa Gu

Editors

\section{2-5 August 2010}

San Diego, California, United States

Sponsored and Published by

SPIE 
The papers included in this volume were part of the technical conference cited on the cover and title page. Papers were selected and subject to review by the editors and conference program committee. Some conference presentations may not be available for publication. The papers published in these proceedings reflect the work and thoughts of the authors and are published herein as submitted. The publisher is not responsible for the validity of the information or for any outcomes resulting from reliance thereon.

Please use the following format to cite material from this book:

Author(s), "Title of Paper," in Earth Observing Systems XV, edited by James J. Butler, Xiaoxiong Xiong, Xingfa GU, Proceedings of SPIE Vol. 7807 (SPIE, Bellingham, WA, 2010) Article CID Number.

ISSN 0277-786X

ISBN 9780819483034

Published by

SPIE

P.O. Box 10, Bellingham, Washington 98227-0010 USA

Telephone +1 3606763290 (Pacific Time) · Fax +1 3606471445

SPIE.org

\section{Copyright (c) 2010, Society of Photo-Optical Instrumentation Engineers}

Copying of material in this book for internal or personal use, or for the internal or personal use of specific clients, beyond the fair use provisions granted by the U.S. Copyright Law is authorized by SPIE subject to payment of copying fees. The Transactional Reporting Service base fee for this volume is $\$ 18.00$ per article (or portion thereof), which should be paid directly to the Copyright Clearance Center (CCC), 222 Rosewood Drive, Danvers, MA 01923. Payment may also be made electronically through CCC Online at copyright.com. Other copying for republication, resale, advertising or promotion, or any form of systematic or multiple reproduction of any material in this book is prohibited except with permission in writing from the publisher. The CCC fee code is 0277-786X/10/\$18.00.

Printed in the United States of America.

Publication of record for individual papers is online in the SPIE Digital Library.

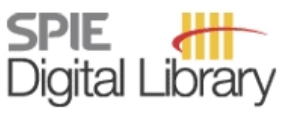

SPIEDigitalLibrary.org

Paper Numbering: Proceedings of SPIE follow an e-First publication model, with papers published first online and then in print and on CD-ROM. Papers are published as they are submitted and meet publication criteria. A unique, consistent, permanent citation identifier (CID) number is assigned to each article at the time of the first publication. Utilization of CIDs allows articles to be fully citable as soon they are published online, and connects the same identifier to all online, print, and electronic versions of the publication. SPIE uses a six-digit CID article numbering system in which:

- The first four digits correspond to the SPIE volume number.

- The last two digits indicate publication order within the volume using a Base 36 numbering system employing both numerals and letters. These two-number sets start with $00,01,02,03,04$, $05,06,07,08,09,0 A, 0 B \ldots 0 Z$, followed by 10-1Z, 20-2Z, etc.

The CID number appears on each page of the manuscript. The complete citation is used on the first page, and an abbreviated version on subsequent pages. Numbers in the index correspond to the last two digits of the six-digit CID number. 


\section{Contents}

vii Conference Committee

\section{SESSION 1 SATELLITE AND AIRBORNE PRE-LAUNCH CALIBRATION}

780702 Pre-launch characterization of spectral response functions for the Clouds and Earth's Radiant Energy System (CERES) instrument sensors [7807-01]

M. Shankar, S. Thomas, Science Systems and Applications, Inc. (United States); K. Priestley, NASA Langley Research Ctr. (United States)

780703 Ground performance measurements of the Glory Aerosol Polarimetry Sensor [7807-02]

S. Persh, Y. J. Shaham, O. Benami, Raytheon Space and Airborne Systems (United States);

B. Cairns, M. I. Mishchenko, NASA Goddard Institute for Space Studies (United States);

J. D. Hein, B. A. Fafaul, NASA Goddard Space Flight Ctr. (United States)

780704 Sensitivity of VIIRS polarization measurements [7807-03]

E. Waluschka, NASA Goddard Space Flight Ctr. (United States)

780705 OLI telescope post-alignment optical performance [7807-04]

M. G. Dittman, B. Firth, Ball Aerospace \& Technologies Corp. (United States)

780707 Test results from an imager for scenes with high dynamic range and low light levels [7807-06]

D. P. Osterman, W. Good, R. Philbrick, L. Schneider, P. Johnson, P. Kaptchen, M. Narciso, Ball Aerospace \& Technologies Corp. (United States)

\section{SESSION 2 GROUND SUPPORT EQUIPMENT/PRE-LAUNCH CALIBRATION}

780708 Characterization of two spectrometers in support of the Landsat Data Continuity Mission [7807-07]

B. C. Johnson, R. D. Saunders, Z. Li, A. Fein, National Institute of Standards and Technology (United States); L. Ong, Science Systems and Applications, Inc. (United States); M. G. Hom, Sigma Space Corp. (United States); R. A. Barnes, Science Applications International Corp. (United States); B. L. Markham, NASA Goddard Space Flight Ctr. (United States)

7807 OA An absolute detector-based spectral radiance source [7807-09] S. W. Brown, National Institute of Standards and Technology (United States); R. D. Saunders, DSK Science, Inc. (United States); Z. Li, Space Dynamics Laboratory (United States); A. Fein, Dickinson College (United States); R. A. Barnes, Science Applications International Corp. (United States)

7807 OB Supercontinuum fiber laser source for reflectance calibrations in remote sensing [7807-10] C. J. Zarobila, Jung Research \& Development Corp. (United States) and National Institute of Standards and Technology (United States); H. J. Patrick, National Institute of Standards and Technology (United States) 
7807 OD On-orbit solar calibrations using the Clouds and Earth's Radiant Energy System (CERES) in-flight calibration system [7807-12]

R. S. Wilson, Science Systems and Applications, Inc. (United States); K. J. Priestley, NASA Langley Research Ctr. (United States); S. Thomas, P. Hess, Science Systems and Applications, Inc. (United States)

7807 OE Temporal decrease of the PARASOL radiometric sensitivity: in-flight characterization of the multi-angular aspect [7807-13]

B. Fougnie, Ctr. National d'Études Spatiales (France)

7807 OF On-orbit models of the CALIOP lidar for enabling future mission design [7807-14] M. Stephens, C. Weimer, E. Saiki, M. Lieber, Ball Aerospace \& Technologies Corp. (United States)

7807 OG Space environment's effect on MODIS calibration [7807-15]

J. L. Dodd, B. N. Wenny, K. Chiang, Sigma Space Corp. (United States); X. Xiong, NASA Goddard Space Flight Ctr. (United States)

\section{SESSION 4 POST-LAUNCH CALIBRATION AND VALIDATION II}

$7807 \mathrm{OH} \quad$ Study of instrument temperature effect on MODIS thermal emissive band responses [7807-16]

T. Chang, Sigma Space Corp. (United States); X. Xiong, NASA Goddard Space Flight Ctr. (United States)

7807 OI Using lunar observations to assess Terra MODIS thermal emissive bands calibration [7807-17] X. Xiong, NASA Goddard Space Flight Ctr. (United States); H. Chen, Sigma Space Corp. (United States)

7807 OJ Comparison of AIRS and IASI co-located radiances for cold scenes [7807-18] D. A. Elliott, H. H. Aumann, S. E. Broberg, Jet Propulsion Lab. (United States)

7807 OK Analysis of AIRS and IASI system performance under clear and cloudy conditions [7807-19] H. H. Aumann, Jet Propulsion Lab. (United States); L. L. Strow, Univ. of Maryland, Baltimore County (United States)

\section{SESSION $5 \quad$ NEW INSTRUMENTS AND MISSIONS}

$7807 \mathrm{OL}$ Evolution of satellite imagers and sounders and for low Earth orbit and technology directions at NASA [7807-20]

T. S. Pagano, Jet Propulsion Lab. (United States); C. R. McClain, NASA Goddard Space Flight Ctr. (United States)

7807 OM On-board calibration of the spectral response functions of the Advanced Baseline Imager's thermal IR channels by observation of the planet Mercury [7807-22]

J. C. Bremer, Research Support Instruments, Inc. (United States) 
7807 ON CERES FM5 and FM6: continuity of observations to support a multi-decadal earth radiation budget climate data record [7807-23]

K. J. Priestley, N. G. Loeb, NASA Langley Research Ctr. (United States); S. S. Thomas, Science Systems and Applications, Inc. (United States); G. L. Smith, National Institute for Aerospace (United States)

$780700 \quad$ Inflatable antenna for earth observing systems [7807-24]

H. Wang, Ctr. for Space Science and Applied Research (China); F. Guan, Y. XU, Zhejiang

Univ. (China); M. Yi, Ctr. for Space Science and Applied Research (China)

\section{SESSION 6 VICARIOUS CALIBRATION/DATA AND DATA SYSTEM I}

7807 OR Recent results from the Radiometric Calibration Test Site (RadCaTS) at Railroad Valley, Nevada [7807-27]

J. S. Czapla-Myers, N. P. Leisso, College of Optical Sciences, The Univ. of Arizona (United States)

7807 OS Climatology of oceanic zones suitable for in-flight calibration of space sensors [7807-28] B. Fougnie, Ctr. National d'Études Spatiales (France); J. Llido, L. Gross-Colzy, Cap Gemini (France); P. Henry, D. Blumstein, Ctr. National d'Études Spatiales (France)

7807 OT Stellar calibration of the ROLO lunar radiometric reference [7807-29]

T. C. Stone, U.S. Geological Survey (United States)

\section{SESSION 7 VICARIOUS CALIBRATION/DATA AND DATA SYSTEM II}

7807 OV Application of Wavelet Transform (WT) on canopy hyperspectral data for soybean Leaf Area Index (LAI) estimation in the Songnen Plain, China [7807-31]

D. LU, Jilin Institute of Architecture and Civil Engineering (China); K. Song, Northeast Institute of Geography and Agroecology (China) and Indiana Univ.-Purdue Univ. at Indianaplos (United States); Z. Wang, Northeast Institute of Geography and Agroecology (China)

\section{SESSION 8 CHINESE REMOTE SENSING AND APPLICATIONS I}

7807 OW High-resolution Directional Polarimetric Camera (DPC) used in the remote sensing of aerosol properties (Invited Paper) [7807-32]

X. Gu, Institute of Remote Sensing Applications (China) and Chinese National Space Administration (China); Q. Yanli, Anhui Institute of Optics and Fine Mechanics (China); J. Wang, T. Yu, T. Cheng, Institute of Remote Sensing Applications (China) and Chinese National Space Administration (China)

7807 OX Simulation of HY-2 scatterometer and analysis of wind field retrieval (Invited Paper) [7807-33]

M. Lin, X. Jiang, X. Xie, National Satellite Ocean Application Service (China)

7807 OY Spaceborne laser rangefinder ranging sensitivity and accuracy analysis [7807-34] J. Wang, R. Shu, G. Huang, J. Jia, Shanghai Institute of Technical Physics (China) 
7807 OZ CASMSAR: the first Chinese airborne SAR mapping system [7807-35]

J. Zhang, Z. Wang, G. Huang, Chinese Academy of Surveying and Mapping (China);

Z. Zhao, Chinese Academy of Surveying and Mapping (China) and Wuhan Univ. (China);

L. Lu, Chinese Academy of Surveying and Mapping (China)

\section{SESSION 9 CHINESE REMOTE SENSING AND APPLICATIONS II}

780714 Design and implementation of ground data processing system for hyperspectral satellite in China [7807-39]

D. Wang, China Aero Geophysical Survey \& Remote Sensing Ctr. for Land and Resources

(China); Z. Li, China Geological Survey Bureau (China); H. Fang, F. Dang, Q. Yang, R. Yang,

China Aero Geophysical Survey \& Remote Sensing Ctr. for Land and Resources (China)

780717 An optimization detection angle for polarization measurement [7807-45]

X. Jian, C. Zhang, Xi'an Jiaotong Univ. (China) and Key Lab. of Ministry of Education (China);

B. Zhao, Xi'an Institute of Optics and Precision Mechanics (China)

\section{POSTER SESSION}

780718 Tracking long-term stability of Aqua MODIS and AIRS at different scan angles [7807-44]

Y. Xie, George Mason Univ. (United States); A. Wu, Sigma Space Corp. (United States);

$X$. Xiong, NASA Goddard Space Flight Ctr. (United States)

7807 1A Calibration support for NPP VIIRS SDR assessment [7807-47]

K.-F. Chiang, A. Wu, J. Sun, Sigma Space Corp. (United States); M. R. Schwaller, X. Xiong, NASA Goddard Space Flight Ctr. (United States)

7807 IE Characterization of Terra MODIS blackbody uniformity and stability [7807-51]

X. Xiong, NASA Goddard Space Flight Ctr. (United States); S. Madhavan, Science Systems and Applications, Inc. (United States)

7807 IF MODIS calibration algorithm improvements developed for Collection 6 Level-1B [7807-52] B. N. Wenny, J. Sun, Sigma Space Corp. (United States); X. Xiong, NASA Goddard Space Flight Ctr. (United States); A. Wu, H. Chen, Sigma Space Corp. (United States); A. Angal, Science Systems and Applications, Inc. (United States); T. Choi, N. Chen, Sigma Space Corp. (United States); S. Madhavan, Science Systems and Applications, Inc. (United States);

X. Geng, J. Kuyper, L. Tan, Sigma Space Corp. (United States)

Author Index 


\title{
Conference Committee
}

\author{
Program Track Chair
}

Allen H.-L. Huang, University of Wisconsin, Madison (United States)

Conference Chairs

James J. Butler, NASA Goddard Space Flight Center (United States)

Xiaoxiong Xiong, NASA Goddard Space Flight Center (United States)

Xingfa Gu, Institute of Remote Sensing Applications (China)

Program Committee

Philip E. Ardanuy, Raytheon Intelligence and Information Systems (United States)

Robert A. Barnes, NASA Goddard Space Flight Center (United States)

Jeffrey S. Czapla-Myers, College of Optical Sciences, The University of Arizona (United States)

Armin W. Doerry, Sandia National Laboratories (United States)

Thomas S. Pagano, Jet Propulsion Laboratory (United States)

Jeffery J. Puschell, Raytheon Space and Airborne Systems (United States)

Carl F. Schueler, Orbital Sciences Corporation (United States)

Session Chairs

1 Satellite and Airborne Pre-launch Calibration

Robert A. Barnes, NASA Goddard Space Flight Center (United States)

James J. Butler, NASA Goddard Space Flight Center (United States)

2 Ground Support Equipment/Pre-launch Calibration

Jeffrey S. Czapla-Myers, College of Optical Sciences, The University of Arizona (United States)

3 Post-launch Calibration and Validation I

Thomas S. Pagano, Jet Propulsion Laboratory (United States)

4 Post-launch Calibration and Validation II

Philip E. Ardanuy, Raytheon Intelligence and Information Systems (United States) 
$5 \quad$ New Instruments and Missions

Jeffery J. Puschell, Raytheon Space and Airborne Systems (United States)

6 Vicarious Calibration/Data and Data System I

Carl F. Schueler, Orbital Sciences Corporation (United States)

Armin W. Doerry, Sandia National Laboratories (United States)

7 Vicarious Calibration/Data and Data System II

Carl F. Schueler, Orbital Sciences Corporation (United States)

Armin W. Doerry, Sandia National Laboratories (United States)

8 Chinese Remote Sensing and Applications I

Xiaoxiong Xiong, NASA Goddard Space Flight Center (United States)

9 Chinese Remote Sensing and Applications II

Xingfa Gu, Institute of Remote Sensing Applications (China) 